\section{Xylodiol from Xylopia langsdorfiana induces apoptosis in HL60 cells}

\author{
Marianna Vieira S. Castello-Branco, ${ }^{*}$, Josean F. Tavares, ${ }^{1}$ \\ Marcelo S. Silva, ${ }^{1}$ José Maria Barbosa Filho, ${ }^{1}$ Maristella C. \\ Anazetti, ${ }^{2,3}$ Lucas Frungillo, ${ }^{2}$ Marcela Haun, ${ }^{2}$ Margareth $F . F$. \\ Melo Diniz, ${ }^{1}$ Patrícia S. Melo ${ }^{2,3}$
}

${ }^{1}$ Laboratório de Tecnologia Farmacêutica, Universidade Federal da Paraíba, Brazil, ${ }^{2}$ Departamento de Bioquímica, Instituto de Biologia, Universidade Estadual de Campinas, Brazil,

${ }^{3}$ Faculdades Integradas Metropolitanas de Campinas, Brazil.
Revista Brasileira de Farmacognosia Brazilian Journal of Pharmacognosy 21(6): 1035-1042, Nov./Dec. 2011

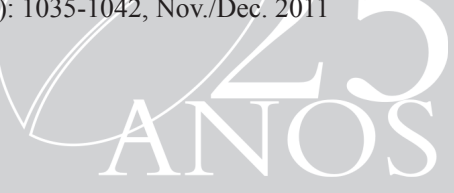

\section{Article}

\begin{abstract}
An atisane diterpene was isolated from Xylopia langsdorfiana St. Hilaire \& Tulasne, Annonaceae, leaves, ent-atisane- $7 \alpha, 16 \alpha$-diol (xylodiol). Preliminary study showed that xylodiol was cytotoxic and induced differentiation on human leukemia cell lines. However, the molecular mechanisms of xylodiol-mediated cytotoxicity have not been fully defined. Thus, we investigated the anti-tumor effect of xylodiol in human leukemia HL60 cell line. Xylodiol induced apoptosis and necrosis. HL60 cells treated with xylodiol showed biochemical changes characteristic of apoptosis, including caspases-8, -9 and -3 activation and loss of mitochondrial transmembrane potential $\left(\Delta \psi_{\mathrm{m}}\right)$. However, there was a condensation rather than swelling of mitochondria. Moreover, the formation of condensed mitochondria and the loss of $\Delta \psi_{\mathrm{m}}$ occurred downstream of caspase activation. Cyclosporine A did not protect HL60 cells from the cytotoxic effects of xylodiol, suggesting that the loss of $\Delta \psi_{\mathrm{m}}$ is a late event in xylodiol-induced apoptosis. Oxidative stress was involved in xylodiol-induced apoptosis. Thus, we conclude that activated caspases cleave cellular proteins resulting in mitochondrial damage leading to mitochondrial condensation, loss of $\Delta \psi_{\mathrm{m}}$ and ROS release from the mitochondria. ROS can further induce and maintain a collapse of $\Delta \psi_{\mathrm{m}}$ leading to cellular damage through oxidation of lipids and proteins resulting in apoptotic cell death.
\end{abstract}

Received 24 Jun 2010

Accepted 13 Apr 2011

Available online 5 Aug 2011
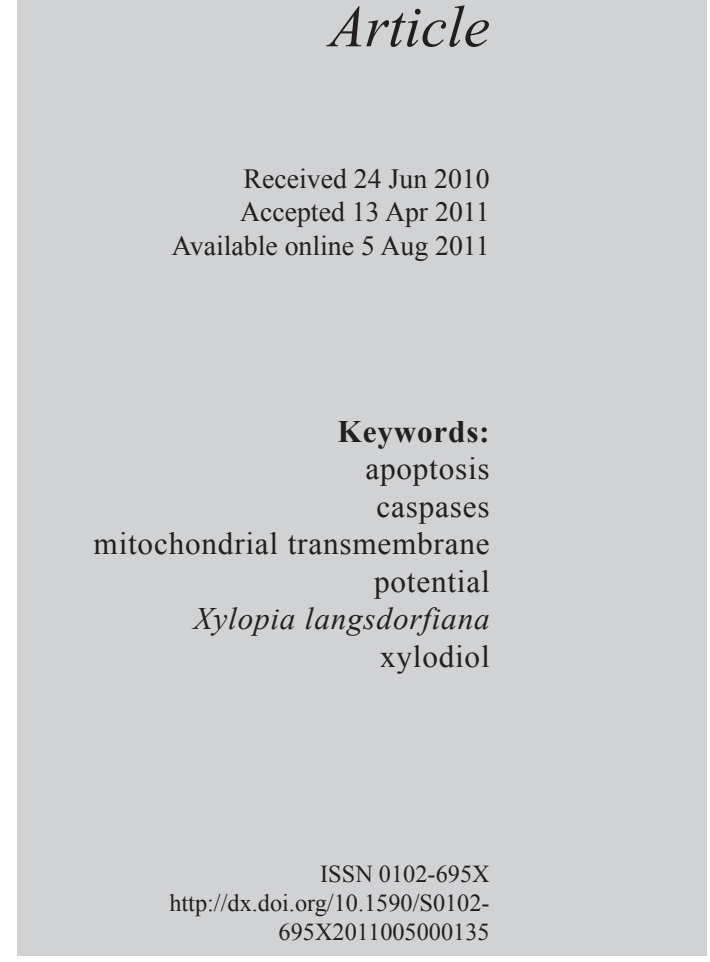

\section{Introduction}

Xylodiol (1), an atisane diterpene, was isolated from Xylopia langsdorfiana St.Hilaire \& Tulasne, Annonaceae, leaves and characterized as ent-atisan$7 \alpha, 16 \alpha$-diol (Tavares et al., 2007). Atisane diterpenes are rare in the Annonaceae family, having been recorded only in Xylopia aromatica (Morais \& Roque, 1988). This group of compounds is little studied biologically thus far. However, other atisane-type diterpenes showed anti-HIV (Sun et al., 2003) and insecticidal activities, and are cytotoxic to mouse leukemia cells P388 (Perry et al., 2001). We have previously reported that xylodiol inhibits cell growth and induces differentiation in human leukemia cell lines (HL60, U937 and K562) (Castello-Branco et al., 2009). Moreover, xylodiol showed weak cytotoxicity against V79 cells and rat hepatocytes (Tavares et al., 2007).

The ability to induce cell apoptosis is an important property of candidate anti-cancer drugs. Two major pathways, the Fas/TNF death receptor pathway and the mitochondria-dependent pathway, lead to the activation of caspases and consequent apoptosis in mammalian cells.<smiles></smiles>

1

Death receptor stimulation activates an extrinsic apoptotic program which results in caspase-8 activation (Thorburn, 2004). Caspase- 8 directly activates effectors caspases including caspase- 3 , one of the major caspases participating in the execution phase of apoptosis. Activated caspase- 3 cleaves many substrates, including poly (ADP-ribose) polymerase (PARP), a DNA repair enzyme, which leads to inevitable cell death. In addition, caspase- 8 can activate Bid, which then triggers the mitochondrial pathway (Liu et al., 2006). In this case, the mitochondrial (intrinsic) pathway is thought 
to be an amplifier signal of the extrinsic pathway. It has been proved that in mitochondrial-mediated apoptosis, a central role is played by mitochondrial permeability transition (MPT), a process that leads to an increase in inner membrane permeability (Ly et al., 2003). This phenomenon is regulated by the opening of a large conductance channel known as the permeability transition pore (MPTP). Opening of this non-selective pore provokes the dissipation of inner transmembrane potential $(\Delta \psi \mathrm{m})$, matrix swelling and outer membrane disruption, thus leading to the release of apoptogenic factors including cytochrome c. The released cytochrome c, together with Apaf-1, activates caspase-9, which in turn proteolytically activates downstream caspase-3 (Jiang \& Wang, 2004).

Apoptosis implicates also reactive oxygen species (ROS)-dependent mechanisms. A role for oxidative stress in the induction of apoptosis is suggested by the observations that low levels of ROS induce apoptosis whereas antioxidants such as $\mathrm{N}$-acetylcysteine (NAC) inhibit cell death. Additionally, ROS generation occurs following the treatment of cells with various agents, including chemotherapeutic drugs (Chandra et al., 2003).

In the present study, we investigated the antiproliferative and apoptosis-inducing effects of xylodiol in human leukemia HL60 cell line, and discuss the possible mechanisms.

\section{Materials and Methods}

Drug

Xylodiol (1) was obtained from Xylopia langsdorfiana St.Hilaire \& Tulasne, Annonaceae, leaves as previously described (Tavares et al., 2007).

\section{Cell culture}

The HL60 cells, derived from a patient with acute promyelocytic leukemia, were of the laboratory of cellular metabolism and regulation kindly provided by Dr Rui Curi, Department of Physiology and Biophysic, Institute of Biomedical Sciences, USP, São Paulo, Brazil. HL60 cells were maintained in RPMI 1640 (Sigma $\left.{ }^{\circledR}\right)$ supplemented with 10\% FBS $\left(\right.$ Sigma $\left.^{\circledR}\right)$, $100 \mathrm{IU} / \mathrm{mL}$ penicillin and $100 \mu \mathrm{g} / \mathrm{mL}$ streptomycin $\left(\mathrm{Sigma}^{\circledR}\right)$ at $37{ }^{\circ} \mathrm{C}$ in a humidified atmosphere of $5 \%$ $\mathrm{CO}_{2}$ and $95 \%$ air.

\section{Annexin V-FITC}

Apoptotic cells were detected using ApoDETECTTM Annexin V-FITC kit obtained from Zymed Laboratories ${ }^{\circledR}$ Inc., USA. HL60 cells $\left(3 \times 10^{5}\right.$ cells $/ \mathrm{mL}$ ) were treated with 0 (control), 50, 100 and $150 \mu \mathrm{M}$ xylodiol for 12, 24, 48 and $72 \mathrm{~h}$. After washing in PBS, $\mathrm{pH} 7.4$, the cells $\left(1 \times 10^{6}\right.$ cells $\left./ \mathrm{mL}\right)$ were resuspended in binding buffer and annexin V-FITC was added. The cells were incubated at room temperature for $10 \mathrm{~min}$ and washed with binding buffer (10 mM Hepes/ $\mathrm{NaOH}, \mathrm{pH}$ 7.4, $140 \mathrm{mM} \mathrm{NaCl}, 2.5 \mathrm{mM} \mathrm{CaCl}_{2}$ ). After the addition of $20 \mu \mathrm{g} / \mathrm{mL}$ propidium iodide (Sigma), the cells were analyzed by flow cytometry using a FACS Calibur flow cytometer (Becton Dickinson, San Jose, CA, USA). Data were acquired with CellQuest acquisition software, version 3.3 (BD Biosciences). A total of 10000 events were collected for each sample and analyzed with WinMDI, version 2.8.

\section{Assay for mitochondrial swelling}

For the detection of mitochondrial swelling, the mitochondria were isolated from HL60 cells after treatment with $0,50,100$ and $150 \mu \mathrm{M}$ xylodiol for 3 , 6, 12 and $24 \mathrm{~h}$, according to Schneider \& Hogeboom (1950) with some modifications. The cells were centrifuged at $12100 \times g$ for $10 \mathrm{~min}$ at 0 to $4{ }^{\circ} \mathrm{C}$. The pellet was suspended in $250 \mathrm{mM}$ sucrose containing $0.3 \mathrm{mM}$ EGTA buffered with $1.0 \mathrm{mM}$ Hepes, and again centrifuged under the same conditions. The pellet was suspended in $250 \mathrm{mM}$ sucrose, obtaining a mitochondrial suspension approaching a concentration of $100 \mu \mathrm{g} /$ $\mathrm{mL}$ protein, determined by the Bradford method. Mitochondrial swelling was determined according to Anazetti et al. (2003) with some modifications. The mitochondria were suspended in CFS buffer (220 $\mathrm{mM}$ mannitol/68 mM sucrose/2.0 $\mathrm{mM} \mathrm{NaCl} / 5.0 \mathrm{mM}$ $\mathrm{KH}_{2} \mathrm{PO}_{4} / 2.0 \mathrm{mM} \mathrm{MgCl}_{2} / 10 \mathrm{mM}$ Hepes-NaOH, $\mathrm{pH}$ 7.4/5.0 mM succinate $/ 2.0 \mu \mathrm{M}$ rotenone). Absorbance was measured at $520 \mathrm{~nm}$ at indicated times for $15 \mathrm{~min}$ at $25^{\circ} \mathrm{C}$ using a spectrophotometer (Beckman DU640B). A decreased absorbance is consistent with an increase in mitochondrial swelling.

\section{Assay for mitochondrial permeability transition}

The mitochondrial membrane potential (MMP) was evaluated in HL60 cells after treatment with 0, 50, 100 and $150 \mu \mathrm{M}$ xylodiol for $12,24,48$ and $72 \mathrm{~h}$. Cells ( 1 x $10^{6}$ cells) were centrifuged and resuspended in phosphate buffer. JC-1 (BD Biosciences ${ }^{\circledR}$ ) was added at a final concentration of $5 \mathrm{ng} / \mathrm{mL}$. After washing with cold PBS, the samples were analyzed by flow cytometer. JC-1 emits light at red and green wavelengths according to the concentrations absorbed by the mitochondria: at a normal membrane potential, JC-1 forms aggregates which emit a green-orange fluorescence, but decreases in the MMP values result with an increase in JC-1 monomer, which then emits 
only green fluorescence. Thus, the decreased JC-1 fluorescence ratio of red aggregates/green monomers linked to the loss of $\Delta \psi \mathrm{m}$ was detected. The cells were analyzed by flow cytometry using a FACS Calibur flow cytometer (Becton Dickinson, San Jose, CA, USA).

Activation of caspase-3, -8 and -9 assay

Caspase activities were measured using Caspase Detection Kits by flow cytometry $\left(\right.$ Calbiochem $\left.{ }^{\circledR}\right)$. The assays were based on the measurement of fluorescence intensity by flow cytometry of the inhibitor conjugated to FITC, the fluorescent markers FITC-DEVD-FMK, FITCIETD-FMK, FITC-LEHD-FMK, which bind to activated caspase-3, -8 and -9 , respectively. HL60 cells at $1 \times 10^{6} /$ $\mathrm{mL}$ were incubated with xylodiol $(0,50,100$ and $150 \mu \mathrm{M})$ for $3,6,12$ and $24 \mathrm{~h}$ at $37^{\circ} \mathrm{C}$ in a $5 \% \mathrm{CO}_{2}$ incubator. The cells were separated into $300-\mu \mathrm{L}$ volumes for each of the induced and control cultures in 1,5 mL tubes, and then, $1 \mu \mathrm{L}$ of inhibitor conjugated to FITC, for each caspase, was added to each tube and the contents incubated for $1 \mathrm{~h}$. The cells were centrifuged and the pellet was resuspended in $0.5 \mathrm{~mL}$ of wash buffer and again centrifuged under the same conditions. The pellet was resuspended in $300 \mu \mathrm{L}$ of wash buffer and placed on ice. The cells were analyzed by flow cytometry using a FACS Calibur flow cytometer (Becton Dickinson, San Jose, CA, USA).

Measurement of lipid peroxidation by the TBARS assay

The extent of xylodiol-induced lipid peroxidation was determined by the reaction of thiobarbituric acid (TBA) with malondialdehyde (MDA), a product formed by lipid peroxidation (Wallin et al., 1993). The cells were previously treated with xylodiol at different concentrations $(0,50,100$ and 150 $\mu \mathrm{M})$. The assays were carried out according to Salgo \& Pryor (1996), with slight modifications. HL60 cells (5 $\left.\times 10^{6}\right)$ were lysed with $15 \mathrm{mM}$ Tris $/ \mathrm{HCl}(5 \mathrm{~mL})$ for 60 min. The lysate was mixed with $2 \mathrm{~mL}$ of precipitating solution (TCA $0.4 \mathrm{~g} / \mathrm{mL}$ ) followed by incubation with TBA $(6.7 \mathrm{mg} / \mathrm{mL})$ for $15 \mathrm{~min}$ at $100{ }^{\circ} \mathrm{C}$, after which the mixture was centrifuged $(750 \times g$ for $10 \mathrm{~min})$. The relative fluorescence was measured with excitation at $515 \mathrm{~nm}$ and emission at $553 \mathrm{~nm}$ in a Sim-Aminco (SPF 500) spectrophotofluorimeter. The results were expressed as percentages of TBARS formed as compared to the control.

\section{Cell viability}

To assess cell viability and the protective effect of cyclosporine A (CSA), reduced glutathione (GSH) and $\mathrm{N}$-acetylcysteine (NAC), all of them obtained from
Sigma, HL60 cells were seeded $\left(3 \times 10^{5}\right.$ cells $\left./ \mathrm{mL}\right)$ in 96-well plates containing $1 \mu \mathrm{M}$ CSA, $1 \mathrm{mM}$ GSH or 1 $\mathrm{mM}$ NAC, and incubated with different concentrations of xylodiol $(0,50,100$ and $150 \mu \mathrm{M})$ for $72 \mathrm{~h}$. Cell viability was determined by MTT $\left(\operatorname{Sigma}^{\circledR}\right)$ reduction. The tetrazolium reduction assay was performed as described by Denizot \& Lang (1986). Briefly, 0.1 $\mathrm{mL}$ of serum-free medium containing MTT (1 mg/ $\mathrm{mL}$ ) was added to each well. After $4 \mathrm{~h}$ of incubation, the supernatant was removed and the blue formazan product obtained was dissolved in $0.1 \mathrm{~mL}$ ethanol with mixing for 15 min on a microplate shaker, after which the absorbance at $570 \mathrm{~nm}$ was read.

\section{Statistical analysis}

Data for each assay were expressed as means \pm SD of three independent experiments run in four replicates. The results were expressed as percentages of controls and the computer software package "Origin" was used to determine the IC50 values (concentration that produced $50 \%$ inhibition of the parameter evaluated). Statistical comparisons were done using one-way ANOVA or Student's t-test as calculated by Origin, version $6.0 p<0.05$ was considered statistically significant.

\section{Results}

Xylodiol decreases the viability of human leukemia cells HL60

As shown in Figure 1, xylodiol inhibited the growth of HL60 cells in a concentration-dependent manner in the absence of CSA. CSA is one of the most employed mitochondrial permeability transition (MPT) inhibitors. However, the addition of CSA did not protect HL60 cells from the cytotoxic effects of xylodiol.

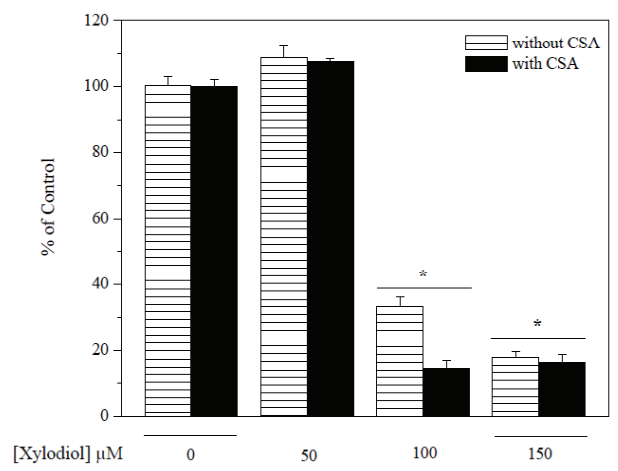

Figure 1. Viability of cultured HL60 cells after treatment with 50,100 and $150 \mu \mathrm{M}$ xylodiol for $72 \mathrm{~h}$ in the presence and absence of CSA. The endpoint evaluated was MTT reduction. All results were expressed as mean $\pm \mathrm{SD}$ of three experiments with four replicates. ${ }^{*} p<0.01$, compared with control. 
Xylodiol induces apoptosis and necrosis in HL60 cells

To further characterize xylodiol-induced apoptosis, we performed a biparametric cytofluorimetric analysis using PI and annexin V-FITC, which stain DNA and phosphatidylserine residues, respectively. Flow cytometric analysis showed that xylodiol induced apoptosis and necrosis in a concentration and timedependent manner in HL60 cells treated with 50, 100 and $150 \mu \mathrm{M}$ xylodiol for 12, 24, 48 and $72 \mathrm{~h}$ (Figure 2 and 3 ). HL60 cells treated with these concentrations for $6 \mathrm{~h}$ did not show any alteration in the annexin $\mathrm{V} /$ PI staining (data not shown). Flow cytometric analysis revealed that at $72 \mathrm{~h}$, the percentage of annexin $\mathrm{V}$ and PI-positive cells (late stages of apoptosis and/or necrotic cells) was high as $81 \%$.

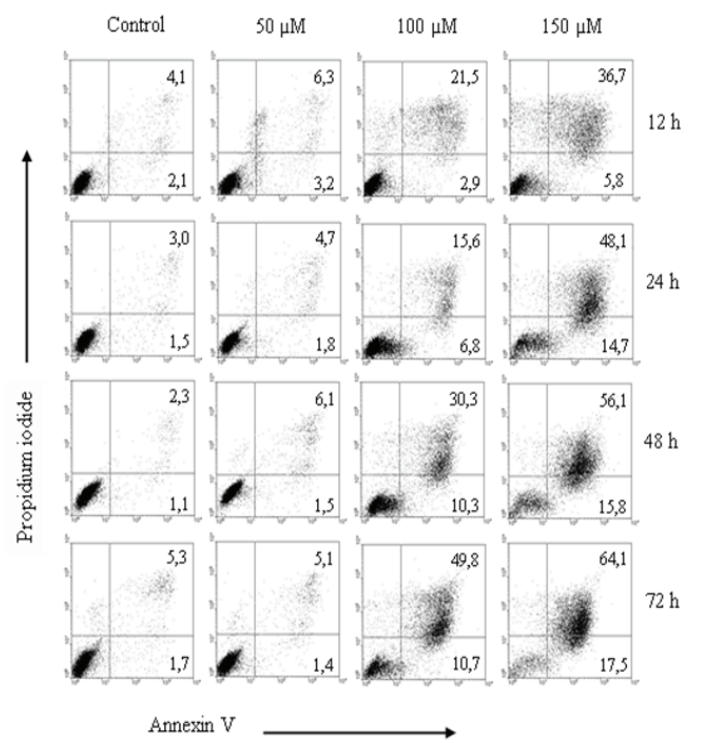

Figure 2. Flow cytometric analysis of HL60 cells treated with xylodiol. Flow cytometry dot plots for the simultaneous binding of annexin V-FITC and propidium iodide (PI) uptake by following exposure of HL60 cells to $0,50,100$ and 150 $\mu \mathrm{M}$ of xylodiol for $12,24,48$ and $72 \mathrm{~h}$. The numbers at the bottom right quadrant of each dot plot represent the percentage of cells in early apoptosis (annexin V-positive, PI-negative) Numbers at the top right quadrant represent the percentage of cells in late apoptosis and/or secondary necrosis (annexin V-positive, PI-positive). The data are representative of three separate experiments.

\section{Xylodiol-induced apoptosis is dependent on caspase} activation

There was a significant increase in caspase- 8 activity in HL60 cells treated with 50, 100 and 150 $\mu \mathrm{M}$ xylodiol as compared to the control (Figure 4A). Caspase- 8 was the first to be activated after $3 \mathrm{~h}$ exposure to 50 and $150 \mu \mathrm{M}$ xylodiol. The peak level of active caspase-8-positive cells at $12 \mathrm{~h}$ was about $65 \%$ at 150 $\mu \mathrm{M}$ xylodiol. A decrease in caspase- 8 activity occurred after $24 \mathrm{~h}$ of treatment. Caspase- 9 was activated only after $12 \mathrm{~h}$ of treatment with $150 \mu \mathrm{M}$ xylodiol (Figure 4 B). Significant activation of caspase- 3 by xylodiol was detected especially after 6,12 and $24 \mathrm{~h}$ of treatment (Figure $4 \mathrm{C}$ ). These results indicate an involvement of caspase- 8 rather than caspase- 9 in apoptosis induced by xylodiol. In addition, these findings strongly suggest that xylodiol induces apoptosis at least partially via the caspase-3 pathway.

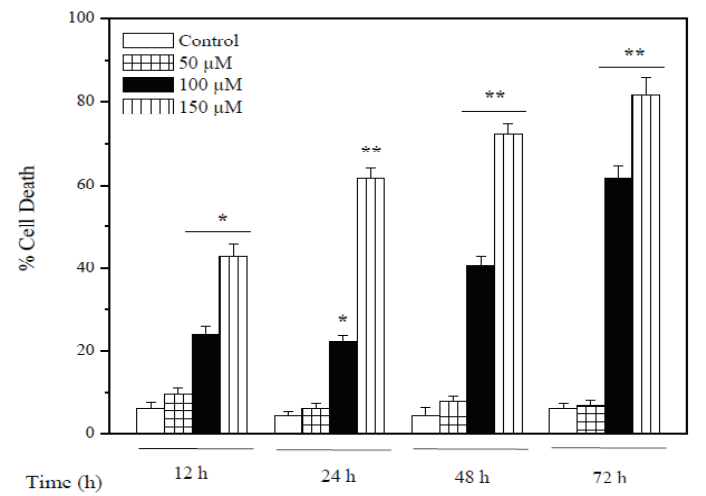

Figure 3. Induction of cell death in response to 50, 100 and $150 \mu \mathrm{M}$ xylodiol. After 12, 24, 48 and $72 \mathrm{~h}$, cells were submitted to annexin V/PI double staining and analyzed by FACS to determine the percent cell death, which included both early and late apoptotic cells. The data presented represent the means of the percent cell death \pm SD from three separate experiments. $* p<0.05$ and $* * p<0.01$, compared with control.

\section{Xylodiol-induced mitochondrial alterations}

An increase in mitochondrial swelling of about $15 \%$ was seen after treatment of HL60 cells with 50 $\mu \mathrm{M}$ xylodiol for 12 and $24 \mathrm{~h}$ (Table 1). In contrast, a decrease in mitochondrial swelling (2.5-26.7\%) occurred in cells treated with 100 and $150 \mu \mathrm{M}$ xylodiol (Table 1). Changes in mitochondrial membrane potential (MMP) were monitored after staining with JC-1. Figure 5 shows a clear increase in the percentage of cells that emitted only green fluorescence after xylodiol treatment (bottom right quadrant) in a concentrationand time dependent manner in HL60 cells treated with 50, 100 and $150 \mu \mathrm{M}$ xylodiol for $12,24,48$ and $72 \mathrm{~h}$. HL60 cells treated with these concentrations for $6 \mathrm{~h}$ did not show any alteration in MMP (data not shown). As shown in Figure 6, there was significant decrease in the ratio of red fluorescence to green fluorescence after exposure to 50,100 and $150 \mu \mathrm{M}$ xylodiol, showing a loss of $\Delta \psi \mathrm{m}$.

Xylodiol-induced apoptosis is associated with oxidative stress 

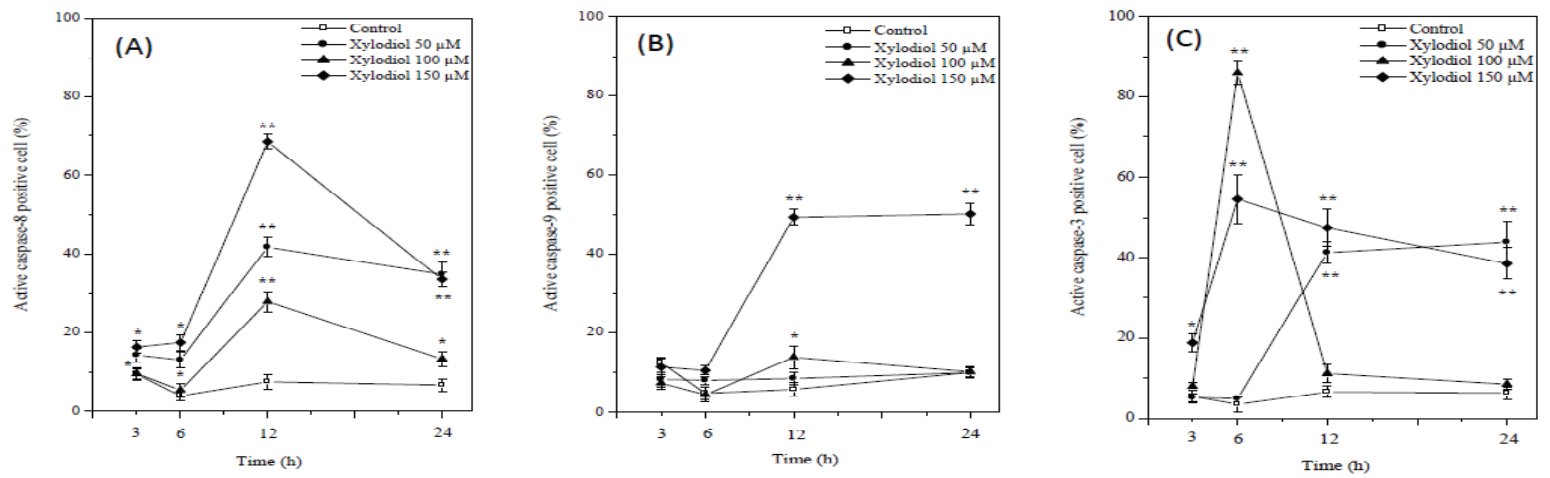

Figure 4. Xylodiol-induced increase in active caspase-8-positive (A), caspase-9-positive (B) and caspase-3-positive (C) HL60 cells. Data are presented as means \pm SD from three separate experiments. ${ }^{*} p<0.05$ and ${ }^{* *} p<0.01$, compared with control.

To investigate any relevance of oxidative stress in xylodiol-induced apoptosis, we examined the degree of lipid peroxidation after treatment with xylodiol for 12, 24 and $48 \mathrm{~h}$. As shown in Figure 7, treatment with 50,100 and $150 \mu \mathrm{M}$ xylodiol for 24 and $48 \mathrm{~h}$ led to a marked increase in the percentage of TBARS formed. TBARS production increased by about $70 \%$ and $80 \%$ after exposure to $100 \mu \mathrm{M}$ xylodiol for 24 and $48 \mathrm{~h}$, respectively.

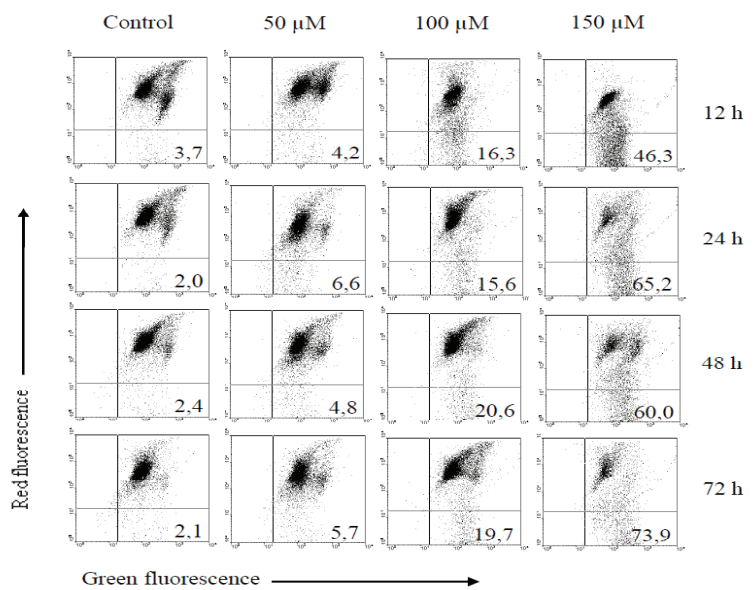

Figure 5. Xylodiol-mediated depolarization of mitochondrial membrane. After 12, 24, 48 and $72 \mathrm{~h}$ of treatment with 50 , 100 and $150 \mu \mathrm{M}$ xylodiol, the cells were stained with the mitochondria selective dye JC-1 and analyzed by FACS. Cells with normal polarized mitochondrial membrane emit green-orange fluorescence (top right quadrant). The number in the bottom right quadrant of each dot plot represents the percentage of cells that emit only green fluorescence indicating loss of $\Delta \psi \mathrm{m}$. The data are representative of three separate experiments.

\section{Antioxidants protect against xylodiol-induced apoptosis}

To examine whether the cytotoxic effect induced by xylodiol in HL60 cells was due to the generation of lipid peroxidation products, cell viability was determined in the presence of the antioxidants GSH and NAC. As revealed in Figure 8, GSH and NAC partially reduced the cytotoxity of xylodiol.

Table 1. Percent increase and decrease (-) in mitochondrial swelling in treated cells compared to control cells. The data are representative of three separate experiments.

\begin{tabular}{lcccc}
\hline \multirow{2}{*}{ Treatment $(\mu \mathrm{M})$} & \multicolumn{4}{c}{ Mitochondrial swelling (\%) } \\
\cline { 2 - 5 } & \multicolumn{4}{c}{ Time of treatment $(\mathrm{h})$} \\
\cline { 2 - 5 } & 3 & 6 & 12 & 24 \\
\hline Xylodiol 50 & -2.5 & -17.1 & 15.2 & 13.8 \\
Xylodiol 100 & -10.5 & -8.3 & -20.2 & -26.7 \\
Xylodiol 150 & -25.7 & -19.0 & -6.4 & -18.9 \\
\hline
\end{tabular}

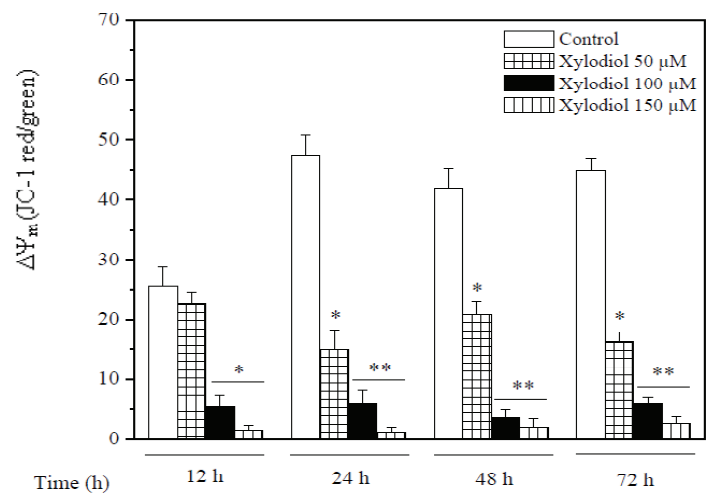

Figure 6. Induction of loss of mitochondrial membrane potential $(\Delta \psi \mathrm{m})$ by xylodiol. HL60 cells treated with 50 , 100 and $150 \mu \mathrm{M}$ xylodiol for $12,24,48$ and $72 \mathrm{~h}$ were analyzed. Alteration in mitochondrial membrane potential was measured by flow cytometry using JC-1 staining. Data presented as means $\pm \mathrm{SD}$ of three independent experiments. ${ }^{*} p<0.05$ and ${ }^{* *} p<0.01$, compared with control. 


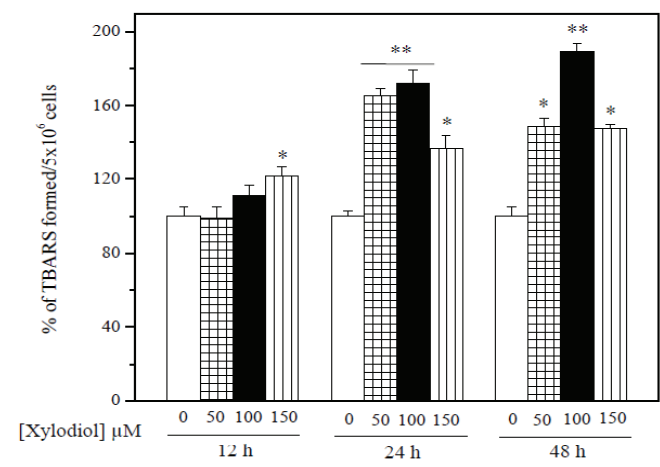

Figure 7. Determination of lipid peroxidation in HL60 cells after exposure to 50,100 and $150 \mu \mathrm{M}$ xylodiol for 12,24 and $48 \mathrm{~h}$. The data are means \pm SD from three independent experiments. ${ }^{*} p<0.05$ and ${ }^{* *} p<0.01$ compared with control.

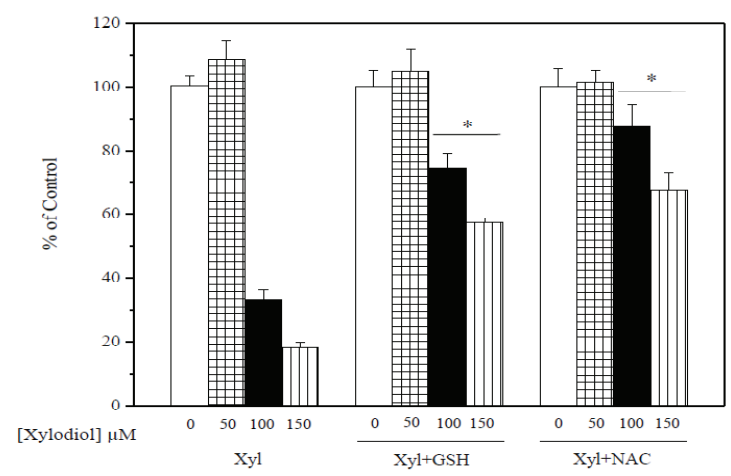

Figure 8. Protective effect of GSH and NAC on the viability of HL60 cells treated with 50,100 and $150 \mu \mathrm{M}$ xylodiol for $72 \mathrm{~h}$ was evaluated by MTT reduction. Each column displays the mean \pm SD of three experiments in four replicates. ${ }^{*} p<0.05$ compared to the groups treated only with xylodiol.

\section{Discussion}

Natural products or their structural relatives comprise about $50 \%$ of the drugs used in cancer chemotherapy (Ito et al., 2004). Anticancer drugs act by interfering with cell proliferation or, in most cases, by inducing programmed cell death, known as apoptosis (Cheson, 2002). Our studies revealed for the first time the anticancer action mechanism of an atisane diterpene.

In apoptotic cells, the membrane phospholipid phosphatidylserine (PS) is translocated from the inner to the outer leaflet of the plasma membrane, thereby exposing PS to the external cellular environment Annexin $\mathrm{V}$ is a phospholipid-binding protein with high affinity for PS. The findings of annexin-V/PI staining indicate that the xylodiol induces apoptosis and necrosis.

The morphological and biochemical changes of apoptosis are orchestrated by a set of cysteine proteinases that are activated during apoptosis, the caspases (Lavrik et al., 2005). In this study, our findings strongly suggest that xylodiol induced apoptosis is at least partially via the caspase- 3 pathway. Caspase- 8 and caspase-9 are initiator caspases in apoptotic pathways triggered by engagement of death receptors and by cytochrome c release from the mitochondria to the cytosol, respectively (Lavrik et al., 2005). Our data indicate an involvement of caspase- 8 rather than caspase-9 in apoptosis induced by xylodiol. The role of membrane death receptor-mediated apoptosis is known to be one of the pathways to caspase- 8 activation. However, it has been reported that anticancer drugs induce apoptosis and caspase- 8 cleavage in a Fasassociated death domain (FADD)-independent manner, suggesting that death receptor activation is not prerequisite for drug-induced caspase- 8 activation (Wesselborg et al., 1999).

The role of the mitochondria in the mechanism of cell death has been studied extensively. In this study, we observed mitochondrial condensation in HL60 cells treated with xylodiol, indicated by a decrease in mitochondrial swelling. Recently, some investigators havereported similar findings of condensed mitochondria in connection with apoptosis (Jia et al., 1997; Zhuang et al., 1998; Ikebukuro et al., 2000). In some systems, there appears to be a progression from the condensed to the ultracondensed form followed by deletion of the organelle (Jia et al., 1997; Zhuang et al., 1998). It has been shown that before cells exhibit common signs of nuclear apoptosis, they undergo a reduction in $\Delta \psi \mathrm{m}$ which is a consequence of the opening of MPTP. It has also been suggested that large amplitude mitochondrial swelling, possibly caused by MPTP opening, is required for the release of apoptogenic factors from mitochondria (Jia et al., 1997; Ly et al., 2003). Other reports suggested that mitochondrial condensation is associated with the apoptotic signaling process and is not a consequence of apoptotic shrinkage (Jia et al., 1997). Zhuang et al. (1998) described the condensation of mitochondria and the reduction in $\Delta \psi \mathrm{m}$ as being downstream of the release of apoptogenic factors, such as cytochrome c. In addition, it was proposed that the formation of condensed mitochondria occurs downstream of caspase activation (Zhuang et al., 1998). Our data support the hypothesis that activated caspases cleave cellular proteins resulting in mitochondrial damage leading to mitochondrial condensation and loss of $\Delta \psi \mathrm{m}$. MPT inhibitors have become useful tools in the study of the processes of cell death in relation to mitochondrial physiology. One of the most employed inhibitors is cyclosporine A (CSA) (Marques-Santos et al., 2006). The observation that CSA did not protect HL60 cells against the cytotoxic effects of xylodiol supports the hypothesis that the loss of $\Delta \psi \mathrm{m}$ is a late 
event in xylodiol-induced apoptosis.

The role of the cellular redox state during apoptosis was examined by determining the extent of lipid peroxidation. The increase in TBARS production occurred at only 24 and 48 h after treatment with xylodiol. Mitochondria are a source of ROS during apoptosis and reduced mitochondrial membrane potential leads to increased generation of ROS and apoptosis (Huang et al., 2006). ROS can further induce and maintain the collapse of $\Delta \psi \mathrm{m}$, leading to cellular damage through the oxidation of lipids and proteins, resulting in apoptotic cell death (Huang et al., 2006). Therefore, we speculate that the generation of ROS could be an important factor in xylodiol-induced apoptosis. In fact, the disruption of mitochondrial membrane potential by xylodiol was accompanied by an increase in TBARS production. In addition, antioxidants such as GSH and NAC were examined in the present study as to whether ROS production is an essential event for xylodiol-induced apoptosis. The ability of the antioxidants to lower the cytotoxic effects of the xylodiol in HL60 cells provides evidence that ROS are intermediates of xylodiolinduced apoptosis.

Altogether, our results reported herein show that xylodiol induces apoptosis and necrosis in HL60 leukemia cells. Our preliminary research of the mechanisms indicates that xylodiol cytotoxicity involves lipid peroxidation and that apoptosis induced by xylodiol is associated with mitochondrial condensation and loss of $\Delta \psi \mathrm{m}$ which occur downstream of caspase activation.

\section{Acknowledgments}

This work was supported by the Brazilian agencies CAPES and FAPESP. Dr. A. Leyva provided English editing of the manuscript.

\section{References}

Anazetti MC, Melo PS, Duran N, Haun M 2003. Comparative cytotoxicity of dimethylamide-crotonin in the promyelocytic leukemia cell line (HL60) and human peripheral blood mononuclear cells. Toxicology 188: 261-274.

Castello-Branco MVS, Anazetti MC, Tavares JF, Lima LF, Silva MS, Haun M, Diniz MFFM, Melo PS 2009. Diterpenes from Xylopia langsdorffiana inhibits cell growth and induce differentiation on human leukemia cells. Z Naturforsch 64: 650-656.

Chandra J, Hackbarth J, Le S, Loegering D, Bone N, Bruzek LM, Narayanan VL, Adjei AA, Kay NE, Tefferi A, Karp JE, Sausville EA, Kaufmann SH 2003. Involvement of reactive oxygen species in adaphostininduced cytotoxicity in human leukemia cells. Blood 102: 4512-4519.

Cheson BD 2002. Hematologic malignancies: new developments and future treatments. Semin Oncol 29: $33-45$.

Denizot F, Lang R 1986. Rapid colorimetric assay for cell growth and survival, modifications to the tetrazolium dye procedure giving improved sensitivity and reliability. J Immunol Methods 89: 271-277.

Huang Y-T, Huang Y-H, Hour T-C, Pan BS, Liu Y-C, Pan M-H 2006. Apoptosis inducing active components from Corbicula fluminea through activation of caspase- 2 and production of reactive oxygen species in human leukemia HL-60 cells. Food Chem Toxicol 44: 12611272 .

Ikebukuro K, Adachi Y, Toki J, Taketani S, Tokunaga R, Hioki K, Ikehara S 2000. Morphological change, loss of $\Delta \psi \mathrm{m}$ and activation of caspases upon apoptosis of colorectal adenocarcinoma induced by 5-FU. Cancer Lett 153: 101-108.

Ito K, Nakazato T, Murakami A, Yamato K, Miyakawa Y, Yamada T, Hozumi N, Ohigashi H, Ikeda Y, Kizaki M 2004. Induction of apoptosis in human myeloid leukemic cells by 1 '-acetoxychavicol acetate through a mitochondrial- and Fas-mediated dual mechanism. Clinical Cancer Res 10: 2120-2130.

Jia L, Dourmashkin RR, Newland AC, Kelsey SM 1997. Mitochondrial ultracondensation but not swelling, is involved in TNF $\alpha$-induced apoptosis in human Tlymphoblastic leukaemic cells. Leukemia Res 21: 973-983.

Jiang X, Wang X 2004. Cytochrome c-mediated apoptosis. Annu Rev Biochem 73: 87-106.

Lavrik IN, Golks A, Krammer PH 2005. Caspases: pharmacological manipulation of cell death. J Clin Invest 115: 2665-2672.

Liu Y-Q, Mu Z-Q, You S, Tashiro S-I, Onodera S, Ikejima T 2006. Fas/FasL signaling allows extracellular-signal regulated kinase to regulate cytochrome c release in oridonin-induced apoptotic U937 cells. Biol Pharm Bull 29: 1873-1879.

Ly JD, Grubb DR, Lawen A 2003. The mitochondrial membrane potential $(\Delta \psi \mathrm{m})$ in apoptosis; an update. Apoptosis 8: 115-128.

Marques-Santos LF, Coqueiro VM, Rumjanek VM 2006. Cyclosporin A does not protect the disruption of the inner mitochondrial membrane potential induced by potassium ionophores in intact K562 cells. Cell Biol Int 30: 197-204.

Morais MPL, Roque NF 1988. Diterpenes from the fruits of Xylopia aromatica. Phytochemistry 27: 3205-3208.

Perry NB, Burgess EJ, Baek S-H, Weavers RT 2001. The first atisane diterpenoids from a liverwort: polyols from Lepidolaena clavigera. Org Lett 3: 4243-4245.

Salgo MG, Pryor WA 1996. Trolox inhibits peroxynitritemediated oxidative stress and apoptosis in rat thymocytes. Arch Biochem Biophys 15: 482488.

Schneider WC, Hogeboom GH 1950. Intracellular distribution of enzymes. V. Further studies of cytochrome $\mathrm{c}$ in rat liver homogenates. J Biol Chem 183: 123-128.

Sun IC, Kashiwada Y, Morris-Natschke SL, Lee KH 2003. Plant-derived terpenoids and analogues as anti-hiv agents. Curr Top Med Chem 3: 155-169. 
Tavares JF, Silva MVB, Queiroga KF, Diniz MFFM, Barbosa-Filho JM, Haun M, Melo PS, Silva MS 2007. Xylodiol, a new atisane diterpenoid from Xylopia langsdorffiana St.-Hil. and Tul. (Annonaceae). Z Naturforsch 62: 742-744.

Thorburn A 2004. Death receptor-induced cell killing. Cellular Signaling 16: 139-144.

Zhuang J, Dinsdale D, Cohen GM 1998. Apoptosis, in human monocytic THP.1 cells, results in the release of cytochrome c from mitochondria prior to their ultracondensation, formation of outer membrane discontinuities and reduction in inner membrane potential. Cell Death Differ 5: 953-962.

Wallin B, Rosengren B, Shertzer HG, Camejo G 1993. Lipoprotein oxidation and measurement of thiobarbituric acid reacting substances formation in a single microtiter plate: its use for evaluation of antioxidants. Anal Biochem 208: 10-15.

Wesselborg S, Engels IH, Rossmann E, Los M, SchulzeOsthoff K 1999. Anticancer drugs induce caspase-8/ FLICE activation and apoptosis in the absence of CD95 receptor/ligand interaction. Blood 93: 30533063.

\section{*Correspondence}

Marianna Vieira S. Castello-Branco

Laboratório de Tecnologia Farmacêutica, Universidade Federal da Paraíba,

Caixa Postal 5009, 58051-970 João Pessoa-PB, Brazil

mariannavbs@1tf.ufpb.br

Tel. +552183 32167003 and 7570 